\title{
Edebiyat Öğretmen Adaylarının Özel Gereksinimli Bireylere Yönelik Tutumları ve Bazı Değişkenlerle İlişkisi
}

\author{
Attitudes of Literature Teacher Candidates Towards Individuals With Special \\ Needs and Relation to Some Variables
}

\author{
Tazegül DEMIR ATALAY \\ Kafkas Üniversitesi, Eğitim Fakültesi, Sosyal Bilimler ve Türkçe Eğitimi Bölümü, Türkçe Eğitimi A.B.D., KARS \\ e-posta: tazeguldemir@gmail.com \\ Ömer ATALAY \\ Kafkas Üniversitesi, İ̈BF, İşletme Bölümü, Sayısal Yöntemler A.B.D., KARS \\ e-posta: omeratalay36@gmail.com
}

Atıf: Demir-Atalay, T. \& Atalay, Ö. (2017). Edebiyat Öğretmen Adaylarının Özel Gereksinimli Bireylere Yönelik Tutumları ve Bazı Değişkenlerle İliş̧kisi. E-Kafkas Eğitim Araştırmaları Dergisi, 4(3), 20-29.

\begin{abstract}
$\ddot{O}_{z \text { zet }}$
Bu çalışmadaki amaç, edebiyat öğretmen adaylarının özel gereksinimli bireylere yönelik tutumlarının tespit edilmesi ve bu durumun çeşitli değişkenlerle arasında ilişkinin olup olmadığının incelenmesidir. Araştırmada betimsel (survey) yöntemlerden tarama yaklaşımı içinde yer alan ilişkisel tarama modeli kullanılmıştır. Araştırmanın evrenini, Kafkas Üniversitesi Eğitim Fakültesi Pedagojik Formasyon Programına devam eden öğrenciler oluşturmaktadır. Bu kapsamda araştırma 2016-2017 bahar döneminde ilgili programa devam eden toplam 297 Türk Dili ve Edebiyatı bölümü öğrencisiyle gerçekleştirilmiştir. Araştırmada Yaralı (2015) tarafindan geliştirilen “Özel Gereksinimli Bireylere Yönelik Tutum Ölçeği” kullanılmıştır. Araştırma sonucunda edebiyat öğretmen adaylarının genel olarak özel gereksinimli bireylere yönelik olarak yüksek oranda olumlu tutumlara sahip olduğu belirlenmiştir. Ayrıca araştırmada edebiyat öğretmeni adaylarının özel gereksinimli bireylere yönelik tutumları, alt boyut bazında da incelenmiştir. Olumsuz tutum, duyarlılık ve beğeni alt boyutları cinsiyet, yaş, mezun olunan lise, baba ve anne eğitim durumu değişkenleri açısından incelenmiştir. Araştırma sonucunda hiçbir alt boyutta ilgili değişkenlere anlamlı bir farklılık tespit edilmemiştir. Dolayısıyla edebiyat öğretmeni adaylarının genel olarak özel gereksinimli bireylere yönelik tutumları, öğretmen adaylarının cinsiyet, yaş, mezun olunan lise, baba ve anne eğitim durumuna göre istatistiki açıdan anlamlı bir farklılığa neden olmamıştır.
\end{abstract}

Anahtar kelimeler: Özel gereksinimli bireyler, tutum, edebiyat öğretmen adayı

\begin{abstract}
The aim of this study is to determine the attitudes of literature teacher candidates towards individuals with special needs and to examine whether this situation is related to various variables. In the study, the relational scan model included in the survey approach from the survey methods was used. Students, who continue to the Caucasian University Faculty of Education Program of Pedagogical Formation, forms the Universe of research. In this context, the research was carried out with a total of 297 Turkish Language and Literature students who continue the related program in the spring semester of 20162017. " An Attitude Scale Towards Individuals With Special Needs" developed by Yaral1 (2015) was used in the study. As a result of the research, it was determined that the literature teacher candidates generally have high positive attitudes towards the individuals with special needs. In addition, the attitudes of the literature teacher candidates towards individuals with special needs were also examined on the sub-dimension basis in the research. The negative attitude, sensitivity and liking subscales were examined in terms of gender, age, graduated high school, father and mother education status variables. As a result of the research, no significant difference was found in the related variables in any sub-dimension. Therefore, generally the attitudes of the literature teacher candidates towards individuals with special needs did not cause a statistically significant difference according to the sex, age, graduated high school, father and mother education status of the teacher candidates.
\end{abstract}

Keywords: Individuals With Special Needs, attitude, literature teacher candidates.

\section{GíRiş}

Eğitim öğretim süreçleri dikkatle incelendiğinde en önemli yapı taşının öğretmen ve öğrenciler olduğunu görmek mümkündür. Dolayısıyla bu süreçte hem öğretmene hem öğrenciye önemli görevler düşmektedir ve her iki unsur da birbiriyle uyum içerisinde çalışmalıdır. Bu uyum özellikle öğrencinin özel gereksinime ihtiyacı olan durumlarda daha da gerekli ve önemlidir. Nitekim eğitim öğretim süreci içerisinde birçok öğrenci özel gereksinimlidir ve öğretmenlerin her öğrencinin bireysel farklılıklarını dikkate alması gerekliliği gibi bu tür öğrencilere çok hassasiyet ve dikkat göstermesi önemlidir. Çünkü bu tür öğrencilerin eğitim öğretim süreci biraz daha karmaşıktır ve öğretmenlerin bu alanda yeterli bilgi ve beceri düzeyine sahip olması gerekmektedir. Sünbül'ün (2001)'de belirttiği gibi eğitim ve öğretimde hedefler ne kadar iyi belirlenirse belirlensin, dersin içeriği 
ne kadar işlevsel seçilip organize edilirse edilsin, o hedefler ve kavrayışlara sahip öğretmenler elinde yürütülmedikçe, eğitimden beklenen sonucun alınması olanaklı değildir.

Öğretim etkinliklerinde belirlenen hedeflere ulaşmada öğretmen, eğitim ortamında en önemli unsurlardan biridir. Bu nedenle öğretmen yetiştirme sürecinin önemli bir süreç olduğu ifade edilebilir. Mesleki bir alan olarak öğretmenlikte alan bilgisi önemli bir yere sahiptir. Bununla birlikte öğretmenlerden birtakım pedagojik bilgi ve beceri göstermeleri beklenmektedir. Öğrenme sürecinin aktif bir biçimde gerçekleşmesi için bireyin psikolojik yapısının da iyi tahlil edilmesi gerekmektedir. "Öğrencilerin gelişim basamaklarını ve sorunlarını tanımadan yalnızca ders anlatmaya dayanan öğretimin, eğitim açısından bir değeri yoktur" (Temizkan, 2008). Bu nedenle ögretmenlerin kendi alanlarında özel gereksinimli bireylerin ilgi ve ihtiyaçlarından hareketle öğretim yapması ve uygun tutuma sahip olması gerekmektedir.

Tutum insan yaşamındaki alanların hemen hemen her aşamasında yer aldığından birçok araştırma alanına da konu olmuştur. Hâl böyle olunca tutum kavramı birçok açıdan tanımlanmıştır. Smith (1968)'e göre tutum, bireye atfedilen ve onun bir psikolojik obje ile ilgili düşünce, duygu ve davranışlarını düzenli bir biçimde oluşturan bir eğilimdir (Akt. Tavşancıl, 2002). Baron ve Bryne'a göre (1977) ise, tutumlar oldukça organize olmuş uzun süreli duygu, inanç ve davranış eğilimleridir (Akt. Cüceloğlu, 2000). Başka araştırmacılar ise tutum kavramını; bir tutum nesnesine yönelik, öğrenilmiş, tutarlı, olumlu ya da olumsuz tepki verme eğilimi (Fishbein ve Ajzen, 1975); nesneler, insanlar ya da olaylar hakkında olumlu ya da olumsuz değerleme ifadeleridir. Tutumlar, insanın bir şey hakkında ne hissettiğini ifade eder (Robbins, 1994). Tutumlar, bizim objelere, fikirlere ve gruplara karşı kabul ya ret meyillerimizi, onlara karşı lehinde ve aleyhinde hislerimizi gösterir (Gay ve Airasian, 2000). Tutum, bir nesneye ilişkin duygu, düşünce ve davranışlardan oluşmaktadır. Ancak, bu boyutlar birbirlerinden bağımsız değildir. Karşlıklı olarak birbirlerini etkiler, birbirinden etkilenir ve çoğu kez aralarında bir tutarlılık bulunur (Aydın, 2000; Özgüven, 2002). Bireylerin davranışlarına yön verebilen psikolojik bir öğe olarak tanımlanmaktadır. (Bain, 1930; Phillips, 2003). Ülgen, (1997) ise tutum kavramını, bireyin davranışlarına yön veren, karar verme sürecinde yanlıllğa neden olan bir olgu olarak tanımlamaktadır. Bu nedenle eğitim öğretim süreçlerinde hem öğretmen bileşeninde hem öğrenci bileşeninde "tutum" kavramı anahtar görevi üstlenmektedir. Özellikle öğretmenlerin öğrencilere yönelik olumlu tutumları eğitim öğretim süreçlerinin başarılı bir şekilde yürütülmesinde etkili olmaktadır. Bütün öğrencilere olduğu gibi özel gereksinimli bireylere yönelik öğretmen tutumu da çok önemlidir. Nitekim bu tür öğrenciler normal öğrencilere göre daha hassas yapıdadırlar.

Özel gereksinimli bireyi, Özgür, (2013) normal eğitim öğretim süreçlerinden faydalanamayan ya da sınırlı olarak faydalanan çocuklar şeklinde tanımlamış ve birkaç adlandırmadan söz etmiştir. Bu adlandırmalar, özürlü, engelli, ayrıcalıklı, özel gereksinimli veya yetersizlikten etkilenmiş şeklindedir. Türk Dil Kurumu (TDK, Erişim tarihi 2017) tarafindan bu tür bireyler "Gelişimin türlü yanlarıyla öğrenme gücü gibi süreçlerin birisi ya da birkaçında yetersiz ya da sakat olan (kişi)." şeklinde tanımlanmıştır ve engelli olarak adlandırılmıştır. Baykoç Dönmez, (2010) bu tür bireylerin etiketlenmeden adlandırılmasını vurgulamış ve dünya ülkelerinde yapılan tanımlamalarla bizde yapılan tanımlamaları bir anlamda eşitlemiş̧tir. Bu tanımlamalar, 'farklı gelişim gösteren çocuklar, özel gereksinimli çocuklar, özel eğitim gerektiren çocuklar, öğrenme farklılığı olan çocuklar, gelişim farklılığı olan çocuklar, özel gereksinimli bireyler' şeklindedir ve bu adlandırmaların özellikle kullanılmasının uygun olduğunu belirtmiştir bu adlandırma ve tanımlardan hareketle özel gereksinimli bireylerin içinde bulunduğu döneme uygun gelişim gösteren ve diğer akranlarıyla ortak özelliklere sahip olan "normal gelişimli birey" kategorisi dışında kalan bireyler olduğunu söylemek mümkündür. Bu durumda normal gelişim gösteren bireylerden farklı özellikler gösteren çocuğun gelişiminde de farklılık olacağı ve bunun o bireyin özel gereksinimine bağlı olarak çeşitli şekil ve derecelerde olacağı söylenebilir.

Özel gereksinimli bireyler için eğitim öğretim süreçlerinde "özel eğitim gerektiren birey veya özel eğitime muhtaç çocuk" ifadesi kullanılmaktadır ve 573 sayılı Kanun Hükmünde Kararname (1997)'de ve 2916 sayılı (1983) Özel Eğitime Muhtaç Çocuklar Kanunu'nda bu ifadeler yerini bulmaktadır. Bu KHK'ya göre özel gereksinimli birey "çeşitli nedenlerle, bireysel özellikleri ve eğitim yeterlilikleri açısından akranlarından beklenilen düzeyden anlamlı farkllık gösteren birey" olarak ifade edilmiştir. Özel Eğitime Muhtaç Çocuklar Kanunu'nda ilgili eksiklikler detaylı olarak ele alınmış ve "beden, zihin, ruh, duygu, sosyal ve sağlık özellikleri ve durumlarındaki olağan dışı ayrılıkları sebebiyle normal eğitim hizmetlerinden yararlanamayan 4-18 yaş grubundaki çocuklar" olarak belirtilmiştir. Milli Eğitim Bakanlığı bünyesinde ise bir yönetmelikle bu tür bireylere değinilmiş ve Özel Eğitim Hizmetleri Yönetmeliği (2006) kapsamında "özel eğitime ihtiyacı olan birey" "çeşitli nedenlerle bireysel ve gelişim özellikleri ile eğitim yeterlilikleri açısından akranlarından beklenilen düzeyden anlamlı farklılık gösteren birey" şeklinde tanımlanarak yayınlanmıştır.

Özel gereksinimli bireylerin normal bireylerden çeşitli açılardan farklı olduğu ve bu farkın da onları ötekileştirdiği söylenebilir. Ülkemizde bu ötekileştirmenin en aza indirilmesi hatta ortadan kaldırılması için çeşitli uygulamalar yapılmaktadır. Bu uygulamalardan eğitim öğretim süreçlerine yansıyanı şüphesiz kaynaştırma eğitimi adı altında belirtilen uygulamadır. Millı̂ Eğitim Bakanlığı Özel Eğitim Hizmetleri Yönetmeliği’nde (2009) kaynaştırma ifadesi "Özel eğitim gerektiren bireylerin, yetersizliği olmayan akranları ile birlikte eğitim ve öğretimlerini resmî ve özel okul öncesi, ilköğretim, orta öğretim ve yaygın eğitim kurumlarında sürdürmeleri esasına dayanan destek eğitim hizmetlerinin sağlandığı özel eğitim uygulamaları" olarak belirtilmiş ve özel 
gereksinimli bireyler normal olarak nitelendirilen öğrencilerle birlikte aynı eğitim öğretim sürecine tabii tutulmuştur. Özkan Yaşaran, (2009) çalışmasında bu durumun gerekliliğini belirtmiş ve bu uygulamanın amacına şöyle değinmiştir: "Özel gereksinimli bireylerin toplumun bir üyesi olarak yaşayabilmeleri için normal gelişim gösteren bireyler gibi eğitimde firsat eşitliğinden yararlanmaları gereklidir. Son yıllarda değişen okul politikaları ve yasalarla en az kısıtlayıcı ortamın desteklenmesi ve özel gereksinimli bireylerin akranlarıyla aynı ortamlarda eğitim görmeleri, diğer bir değişle kaynaştırılmaları fikri kabul edilmektedir" Bu durum da beraberinde öğretmenlerin daha özenli, hassas, dikkatli ve becerili olması gerekliliğini getirmiştir. Nitekim bu tür öğrencilerin diğer öğrenciler tarafindan dışlanması, etiketlenmesi öğretmen tarafindan engellenerek onlarım topluma kazandırılması bu uygulamanın da en önemli unsurudur. $\mathrm{Bu}$ anlamda bütün branşlardaki öğretmenlerin sorumluluğu da artmıştır. Sarı ve Bozgeyikli, (2003) araştırmasında "Bir eğitim türü olan bütünleştirme veya kaynaştırmanın başarısı için sınıf öğretmenleri gibi diğer öğretmenlerin de tutumlarının olumlu yönde gelişebilmesi, özel eğitim dersi almaları ve o yıllardan başlayarak üniversite eğitimleri süresince hazırlanmalarının gerekliliğine değinmiştir. Bu anlamda bütün branşlar gibi edebiyat öğretmenlerinin de sorumluluğu büyüktür. Nitekim edebiyat, dil ve anlatım dersleri bilgi vermenin yanında duygu oluşturma, tutum ve his geliștirme dersi olarak da belirtilebilir. Bu tür özel gereksinimli bireyler bu derslerde daha aktif olabilir ve diğer arkadaşlarıyla etkileşimleri bu derslerde maksimum düzeye çıkarılabilir. Bundan dolayı edebiyat öğretmenlerinin bu tür öğrencilere yönelik tutumları çok önemlidir. Bütün bu durumlardan hareketle bu araştırma edebiyat öğretmen adaylarıyla gerçekleştirilmiştir.

\section{Çalışmanın Amacı}

$\mathrm{Bu}$ çalışmadaki amaç, edebiyat öğretmen adaylarının özel gereksinimli bireylere yönelik tutumlarının tespit edilmesi ve bu durumun çeşitli değişkenlerle arasında ilişkinin olup olmadığının incelenmesidir. $\mathrm{Bu}$ kapsamda araştırmanın özel gereksinimli bireylere yönelik tutumları kapsamında üç alt boyut bulunmaktadır. Bunlar, olumsuz tutum, duyarlılık ve beğeni olarak belirtilebilir. Bu alt boyutların her birinin şu değişkenlerle ilişkisine bakılmıştır: cinsiyet, yaş, mezun olunan lise, baba ve anne eğitim durumu.

\section{YÖNTEM}

Araştırmada betimsel (survey) yöntemlerden tarama yaklaşımı içinde yer alan ilişkisel tarama modeli kullanılmıştır. Tarama modelleri, geçmişte ya da hâlen var olan bir durumu var olduğu şekliyle betimlemeyi amaçlayan araştırma yaklaşımlarıdır (Karasar, 2005:77). Betimleme / survey olarak da adlandırılan bu modeller araştırmaların ilk aşamasını oluşturur; çünkü burada amaç araştırmaya konu olan olguları ve bu olgular arasındaki ilişkileri saptama, sınıflama ve kaydetmedir (Yıldırım ve Şimşek, 2005:56). Betimsel araştırmalarda - Ne, nedir, ne ile ilgilidir, nelerden oluşmaktadır gibi sorulara cevap aranır ve bu gibi incelemeler mevcut durumları, şartları ve özellikleri olduğu gibi ortaya koymaya çalışır. Büyüköztürk vd. 'ne (2008: 22) göre eğitim alanında, sadece durumları ya da olayları betimlemenin ötesinde olası ilişkileri araştırarak olguyu daha iyi anlamaya ve tahminlerde bulunmaya yönelik çalışmalar da yapılmaktadır. Bu yöntemde yer alan ilişkisel tarama modeli, iki ya da daha çok sayıdaki değişken arasındaki birlikte değişimin varlığını ve derecesini belirlemeyi amaçlamaktadır (Karasar, 2005: $81)$.

Çalışma, edebiyat öğretmen adaylarının özel gereksinimli bireylere yönelik tutumlarının tespit edilmesi ve bu durumun çeşitli değişkenlerle arasında ilişkinin olup olmadığının incelenmeyi amaçladığından ilişkisel tarama modeli deseninde yapılandırılmıştır.

\section{Evren ve Örneklem:}

Araştırmanın evrenini, Kafkas Üniversitesi Eğitim Fakültesi Pedagojik Formasyon Programına devam eden edebiyat öğretmeni adayları oluşturmaktadır. Bu kapsamda araştırma 2016-2017 bahar döneminde ilgili programa devam eden toplam 297 Türk Dili ve Edebiyatı Bölümü öğrencisi ile gerçekleştirilmiştir. Aşağıda bu ögrencilere ait yüzde ve frekans bilgileri verilmiştir.

Tablo 1

Ögretmen Adaylarının Cinsiyete Göre Yüzde Ve Frekans Bilgileri

\begin{tabular}{lll}
\hline & Cinsiyet & \\
\hline Kuz & $\mathbf{N}$ & $\%$ \\
\hline Erkek & 159 & 50,2 \\
\hline Toplam & 138 & 43,5 \\
\hline Tablo incelendiŏinde arastırmada pedagojik formasyon programına devam eden 297 öğrenci ile
\end{tabular}

çalıșıldığı bu öğrencilerin \%50,2'sinin erkek; \%43,5'inin ise kız öğrencilerden oluștuğu söylenebilir. Bu orana göre cinsiyet bazında araştırmaya katılan öğrencilerin dağılımı yaklaşık olarak yarı yarıyadır.

\section{Veri Toplama Araçları:}

Araştırmada Yaralı (2015) tarafinda geliştirilen "Özel Gereksinimli Bireylere Yönelik Tutum Ölçeği” kullanılmıştır. Ölçek geliştirme çalışması 2014-2015 eğitim öğretim güz yarıyılında Kafkas Üniversitesi Eğitim 
Fakültesi Türkçe Öğretmenliği, Eğitim Bilimleri (PDR) ve Sınıf Öğretmenliği anabilim dallarında öğrenim gören 180 öğretmen adayı ile gerçekleştirilmiştir. Ölçeğin yapı geçerliliğini belirlemek amacıyla açımlayıcı faktör analizi (AFA) ve doğrulayıcı faktör analizi (DFA) yapılmış olup AFA'da faktörlerin yapısını belirlemek amacıyla temel bileşenler analizi kullanılmıştır. Ölçekten elde edilen puanların içtutarlılık açısından güvenirliğini test etmek amacıyla Cronbach alfa güvenirlik katsayısı, her maddenin alt-üst \%27 gruplarının madde ortalama puanları arasındaki ilişkisiz t-testi, iki yarı test güvenirliği Spearman-Brown korelasyon değeri ve Guttman Split-Half değeri ve her bir maddenin düzeltilmiş toplam madde korelasyonları hesaplanmıştır.

Faktör analizi yapılmadan önce Kaiser-Meyer-Olkin katsayısına (KMO) ve Bartlett küresellik testine bakılmıştır. Araştırmada, ölçeğin KMO değeri 0.855 , Bartlett küresellik testi sonucu da (2341.713, df= 561, p= 0.000 ) olarak bulunmuştur.

Ölçeğe ilişkin yapılan faktör analizi sonucunda, ölçeğin 13 madde olarak 3 faktör altında toplandığı belirlenmiştir. Ölçeğe ait üç faktör sırasıyla; birinci faktörde bulunan maddeler öğretmen adaylarının özel gereksinimli bireylere yönelik ilgi ve zevk almalarından dolayı beğeni olarak, ikinci faktörde yer alan maddeler öğretmen adaylarının özel gereksinimli bireyler ile ilgili daha fazla etkinlik yapılması, kitle iletişim aracında daha fazla yer verilmesi ve özel gereksinimli bireylerin eğitimleri hakkında bir şeyler öğrenmenin önemli olduğunu düşünmesi özel gereksinimli bireylere yönelik duyarlılıklarını gösterdiğinden duyarllllk olarak ve üçüncü faktörde yer alan maddeler ise öğretmen adaylarının, özel gereksinimli öğrencilerin sınıflarında olması ihtimalinin onları korkutması, özel gereksinimli çocukların öğretmeni olmak istememeleri, tercih hakkı verilirse onları sınıflarında istememeleri ve özel gereksinimli bireye sahip ailenin çocuğuna nasıl davrandığı ile ilgilenmemelerinden dolayı olumsuz tutum boyutu olarak isimlendirilmiştir. Ölçeğin geneline ve faktörlere (alt boyutlara) ait güvenirlik katsayıları Tablo 2'de yer almaktadır.

Tablo 2

Faktörler ve Ölçeğin Bütününe Ait Alfa Güvenirlik Katsayıları

\begin{tabular}{lllll}
\hline & Beğeni & Duyarlılık & Olumsuz & \multicolumn{2}{c}{ Ölçeğin } \\
& & \multicolumn{2}{c}{ Tutum } & \multicolumn{1}{c}{ Bütünü } \\
\hline Madde sayısı & 6 & 3 & 4 & .841 \\
\hline Cronbach $\boldsymbol{\alpha}$ & .803 & .812 & .712 & .812, \\
\hline
\end{tabular}

Tablo 2'de görüldüğ̈̈ üzere birinci faktöre (Beğeni) ait $\alpha=.803$, ikinci faktör (Duyarlılık) $\alpha=.812$, üçüncü faktör (Olumsuz Tutum) $\alpha=.712$ ve ölçek geneline ait $\alpha=.841^{\prime}$ dir.

Kişisel Bilgi Formu: Bu form araştırmacı tarafindan oluşturulmuş ve öğrencilerin çeşitli bilgilerini tespit etmeyi amaçlamıştır. Bu bilgiler şunlardır: cinsiyet, yaş, mezun olunan lise, baba ve anne eğitim durumu.

Verilerin Analizi:

Araştırmada öncelikle öğretmen adaylarının kişisel bilgileri ve ölçekte yer alan her bir maddeye verdikleri cevaplar SPSS paket programına girilmiştir. Daha sonra veriler analiz edilirken örnekleme giren bütün cevaplayıcıların özel gereksinimli bireylere yönelik tutum puanları hesaplanmış ve ölçek puanlanırken olumlu ve olumsuz cümleler göz önünde alınarak cevap kategorileri olumludan olumsuza doğru 5, 4, 3, 2, 1 olarak puanlanmıştır. Bu nedenle, ölçekten alınabilecek en yüksek puan 65 ve en düşük puan 13'tür. Özel gereksinimli bireylere yönelik tutum ölçeği maddeleri için aritmetik ortalamaların yorumlanmasında; $1.00-1.80$ aralı̆̆ "Kesinlikle Katılmıyorum", 1.81-2.60 aralığı "Katılmıyorum", 2.61-3.40 aralığı "Kararsızım", 3.41-4.20 aralığı "Katıllyorum" ve 4.21-5.00 aralığı ise "Kesinlikle Katıllyorum" seçeneği olacak şekilde değerlendirilmiştir.

Araştırmada öğrencilere ait bilgiler betimsel istatistiklerden frekans (f) ve yüzde (\%) değerleri kullanılarak, "Özel Gereksinimli Bireylere Yönelik Tutum Ölçeği”'ne göre alt boyutlardaki seviyeleri aritmetik ortalamalarına göre incelenmiştir. Ayrıca edebiyat öğretmen adaylarının özel gereksinimli bireylere yönelik tutumu ile cinsiyet arasındaki ilişsiyi belirlemek için bağımsız gruplar t testi; öğretmen adaylarının özel gereksinimli bireylere yönelik tutumu ile yaş, mezun olunan lise, baba ve anne eğitim durumu değişkenleri arasındaki ilişkiyi belirlemek için bağımsız örneklemler için tek yönlü varyans analizi (ANOVA) kullanılmıştır. Varyans analizi sonucunda farklılı̆̆ın belirlendiği durumlarda, farklılığın hangi gruplar arasında gerçekleştiğini ortaya koymak için LSD testi uygulanmıştır.

\section{BULGULAR}

Araştırma bulguları, edebiyat öğretmen adaylarının özel gereksinimli bireylere yönelik tutum ölçeği alt boyutları olan olumsuz tutum, duyarlılık ve beğeni durumları dikkate alınarak cinsiyet, yaş, mezun olunan lise, baba ve anne eğitim durumu değişkenleri bazında analiz edilmiştir. Devamında ölçek toplam puanına göre aynı alt boyutlar dikkate alınarak analiz edilmiş ve tablolar şeklinde verilmiştir. 
Tablo 3

Edebiyat Öğretmen Adaylarının Özel Gereksinimli Öğrencilere yönelik Tutumlarının Alt Boyut Bazında Cinsiyet Değişkenine Göre Bağımsız Gruplar T-Testi Sonuçları

\begin{tabular}{|c|c|c|c|c|c|c|c|}
\hline & cinsiyet & $\mathbf{N}$ & $\bar{X}$ & SS & Sd & $\mathbf{t}$ & $\mathbf{p}$ \\
\hline \multirow{2}{*}{$\begin{array}{l}\text { Olumsuz } \\
\text { tutum }\end{array}$} & bayan & 155 & 15,8000 & 4,38474 & \multirow[t]{2}{*}{288} & \multirow{2}{*}{1,713} & \multirow{2}{*}{,088 } \\
\hline & erkek & 135 & 14,8815 & 4,69686 & & & \\
\hline \multirow{2}{*}{ duyarlılık } & bayan & 155 & 12,3742 & 3,50352 & \multirow[t]{2}{*}{288} & \multirow{2}{*}{1,333} & \multirow{2}{*}{, 183 } \\
\hline & erkek & 135 & 11,8296 & 3,43933 & & & \\
\hline \multirow{2}{*}{ beğeni } & bayan & 155 & 22,8387 & 6,58854 & \multirow[t]{2}{*}{288} & \multirow{2}{*}{1,055} & \multirow{2}{*}{,292 } \\
\hline & erkek & 135 & 22,0815 & 5,62915 & & & \\
\hline
\end{tabular}

$* \mathrm{p}<, 05$

Tabloya özel gereksinimli bireylere yönelik tutum ölçeği alt boyutları olan olumsuz tutum, duyarlılık ve beğeni durumları cinsiyet değişkenine göre istatistiki anlamda anlamlı bir farklılık oluşturmamıştır. Her bir alt boyutta aritmetik ortalamalar birbirine yakın çıkmıştır ve bu durum öğrencilerin cinsiyet durumlarının özel gereksinimli bireylere yönelik tutumları, duyarlılık ve beğenilerini etkilemediğini ortaya çıkarmıştır

Tablo 4

Edebiyat Öğretmen Adaylarının Özel Gereksinimli Ögrencilere yönelik Tutumlarının Alt Boyut Bazında Yaş Değisşkenine Göre ANOVA Sonuçları

\begin{tabular}{|c|c|c|c|c|c|c|}
\hline \multirow{4}{*}{$\begin{array}{l}\text { Olumsuz } \\
\text { tutum }\end{array}$} & $\begin{array}{l}\text { Varyansın } \\
\text { Kaynağı }\end{array}$ & $\begin{array}{l}\text { Kareler } \\
\text { Toplamı }\end{array}$ & Sd & $\begin{array}{l}\text { Kareler } \\
\text { Ortalaması }\end{array}$ & $\mathbf{F}$ & $\mathbf{p}$ \\
\hline & $\begin{array}{l}\text { Gruplar } \\
\text { Arası }\end{array}$ & 102,646 & 3 & 34,215 & 1,635 & , 182 \\
\hline & Gruplar İçi & 5944,854 & 284 & 20,933 & & \\
\hline & Toplam & 6047,500 & 287 & & & \\
\hline \multirow[t]{3}{*}{ duyarlılık } & $\begin{array}{l}\text { Gruplar } \\
\text { Arası }\end{array}$ & 38,222 & 3 & 12,741 & 1,041 & ,375 \\
\hline & Gruplar İçi & 3474,653 & 284 & 12,235 & & \\
\hline & Toplam & 3512,875 & 287 & & & \\
\hline \multirow{2}{*}{ beğeni } & $\begin{array}{l}\text { Gruplar } \\
\text { Arası } \\
\end{array}$ & 202,723 & 3 & 67,574 & 1,823 & ,143 \\
\hline & Gruplar İçi & 10527,107 & 284 & 37,067 & & \\
\hline
\end{tabular}

$* \mathrm{p}<, 05$

Araştırma kapsamında etkisi araştırılan değişkenlerden biri de yaştır. Bu kapsamda öğrencilerin yaşları sorulmuş ve alınan cevaplar doğrultusunda bütün alt boyutlarla istatistiki açıdan anlamlı bir farklılık bulunup bulunmaması açısından analiz edilmiştir. Sonuç olarak tabloda belirtilen sig. değerleri dikkate alındığında yaş durumunun özel gereksinimli bireylere yönelik olumsuz tutum, duyarlılık ve beğeni alt boyutlarının hiçbirinde anlamlı bir farka sebep olmadığı belirlenmiştir.

Tablo 5

Edebiyat Öğretmen Adaylarının Özel Gereksinimli Ögrrencilere yönelik Tutumlarının Alt Boyut Bazında Mezun Olunan Lise Değişkenine Göre ANOVA Sonuçları

\begin{tabular}{|c|c|c|c|c|c|c|}
\hline \multirow{4}{*}{$\begin{array}{l}\text { Olumsuz } \\
\text { tutum }\end{array}$} & $\begin{array}{l}\text { Varyansın } \\
\text { Kaynağı }\end{array}$ & $\begin{array}{l}\text { Kareler } \\
\text { Toplamı }\end{array}$ & Sd & $\begin{array}{l}\text { Kareler } \\
\text { Ortalaması }\end{array}$ & $\mathbf{F}$ & $\mathbf{p}$ \\
\hline & $\begin{array}{l}\text { Gruplar } \\
\text { Arası }\end{array}$ & 40,952 & 5 & 8,190 & ,382 & ,860 \\
\hline & Gruplar İçi & 4732,290 & 221 & 21,413 & & \\
\hline & Toplam & 4773,242 & 226 & & & \\
\hline \multirow[t]{3}{*}{ duyarlılık } & $\begin{array}{l}\text { Gruplar } \\
\text { Arası }\end{array}$ & 80,453 & 5 & 16,091 & 1,412 & ,221 \\
\hline & Gruplar İçi & 2517,970 & 221 & 11,394 & & \\
\hline & Toplam & 2598,423 & 226 & & & \\
\hline \multirow{3}{*}{ beğeni } & $\begin{array}{l}\text { Gruplar } \\
\text { Arası }\end{array}$ & 196,688 & 5 & 39,338 & 1,217 & ,302 \\
\hline & Gruplar İci & 7143,162 & 221 & 32,322 & & \\
\hline & Toplam & 7339,850 & 226 & & & \\
\hline
\end{tabular}

$* p<, 05$ 
Araştırmada kullanılan diğer bir değişken ise öğretmen adaylarının mezun oldukları lisedir. Bu kapsamda genel lise, Anadolu lisesi, fen lisesi, Anadolu öğretmen lisesi, meslek lisesi ve süper lise seçenekleri sunulmuş ve alınan cevaplar doğrultusunda bütün alt boyutlarla istatistiki açıdan anlamlı bir farklılık olup olmadığ belirlenmeye çalışılmıştır. Sonuç olarak mezun olunan lise değişkeninin özel gereksinimli bireylere yönelik olumsuz tutum, duyarlılık ve beğeni alt boyutlarının hiçbirinde anlamlı bir farka sebep olmadığı tespit edilmiştir.

Tablo 6

Edebiyat Öğretmen Adaylarının Özel Gereksinimli Öğrencilere yönelik Tutumlarının Alt Boyut Bazında Anne ĕ̌itim Durumu Değişkenine Göre ANOVA Sonuçları

\begin{tabular}{|c|c|c|c|c|c|c|}
\hline \multirow{4}{*}{$\begin{array}{l}\text { Olumsuz } \\
\text { tutum }\end{array}$} & $\begin{array}{l}\text { Varyansın } \\
\text { Kaynağı }\end{array}$ & $\begin{array}{l}\text { Kareler } \\
\text { Toplamı }\end{array}$ & Sd & $\begin{array}{l}\text { Kareler } \\
\text { Ortalaması }\end{array}$ & $\mathbf{F}$ & $\mathbf{p}$ \\
\hline & $\begin{array}{l}\text { Gruplar } \\
\text { Arası }\end{array}$ & 94,033 & 4 & 23,508 & 1,073 & ,371 \\
\hline & Gruplar İçi & 5040,665 & 230 & 21,916 & & \\
\hline & Toplam & 5134,698 & 234 & & & \\
\hline \multirow[t]{3}{*}{ duyarlılık } & $\begin{array}{l}\text { Gruplar } \\
\text { Arası }\end{array}$ & 22,087 & 4 & 5,522 & ,468 &, 759 \\
\hline & Gruplar İçi & 2716,023 & 230 & 11,809 & & \\
\hline & Toplam & 2738,111 & 234 & & & \\
\hline \multirow{3}{*}{ beğeni } & $\begin{array}{l}\text { Gruplar } \\
\text { Arası }\end{array}$ & 132,528 & 4 & 33,132 & 1,001 & ,408 \\
\hline & Gruplar İçi & 7616,494 & 230 & 33,115 & & \\
\hline & Toplam & 7749,021 & 234 & & & \\
\hline
\end{tabular}

$* \mathrm{p}<, 05$

Araştırma kapsamında kullanılan bir diğer değişken öğretmen adaylarının annelerine ait eğitim durumu bilgisidir. Bu kapsamda anne eğitim durumu kapsamında okuryazar değil, ilkokul, ortaokul, lise, üniversite ve lisansüstü seçenekleri sunulmuş ve alınan cevaplar doğrultusunda bütün alt boyutlarla istatistiki açıdan anlamlı bir farklılık bulunup bulunmaması açısından analiz edilmiştir. Sonuç olarak tabloda belirtilen sig. değerleri dikkate alındığında anne eğitim durumunun özel gereksinimli bireylere yönelik olumsuz tutum, duyarlılık ve beğeni alt boyutlarında anlamlı bir farklılık oluşturmadığ

Tablo 7

Edebiyat Öğretmen Adaylarının Özel Gereksinimli Öğrencilere yönelik Tutumlarının Alt Boyut Bazında Baba ĕgitim Durumu Değişkenine Göre ANOVA Sonuçları

\begin{tabular}{|c|c|c|c|c|c|c|}
\hline \multirow{4}{*}{$\begin{array}{l}\text { Olumsuz } \\
\text { tutum }\end{array}$} & $\begin{array}{l}\text { Varyansın } \\
\text { Kaynağı }\end{array}$ & $\begin{array}{l}\text { Kareler } \\
\text { Toplamı }\end{array}$ & Sd & $\begin{array}{l}\text { Kareler } \\
\text { Ortalaması }\end{array}$ & $\mathbf{F}$ & $\mathbf{p}$ \\
\hline & $\begin{array}{l}\text { Gruplar } \\
\text { Arası }\end{array}$ & 50,116 & 4 & 12,529 & ,564 & ,689 \\
\hline & Gruplar İçi & 5084,316 & 229 & 22,202 & & \\
\hline & Toplam & 5134,432 & 233 & & & \\
\hline \multirow[t]{3}{*}{ duyarlılık } & $\begin{array}{l}\text { Gruplar } \\
\text { Arası }\end{array}$ & 36,735 & 4 & 9,184 & ,780 & ,539 \\
\hline & Gruplar İçi & 2696,209 & 229 & 11,774 & & \\
\hline & Toplam & 2732,944 & 233 & & & \\
\hline \multirow{3}{*}{ beğeni } & $\begin{array}{l}\text { Gruplar } \\
\text { Arası }\end{array}$ & 273,941 & 4 & 68,485 & 2,099 & ,082 \\
\hline & Gruplar İçi & 7472,097 & 229 & 32,629 & & \\
\hline & Toplam & 7746,038 & 233 & & & \\
\hline
\end{tabular}

$* \mathrm{p}<, 05$

Baba eğitim durumu değişkeni kapsamında okuryazar değil, ilkokul, ortaokul, lise, üniversite ve lisansüstü seçenekleri sunulmuş ve alınan cevaplar doğrultusunda bütün alt boyutlarla istatistiki açıdan anlamlı bir farklılık bulunup bulunmaması açısından analiz edilmiştir. Tablo incelendiğinde araştırma kapsamında kullanılan öğretmen adaylarının babalarına ait eğitim durumunun özel gereksinimli bireylere yönelik olumsuz tutum, duyarlılık ve beğeni alt boyutlarında anlamlı bir farklılık oluşturmadığı görülmektedir.

Çalışmada analiz edilen bir diğer özellik ise edebiyat öğretmen adaylarının özel gereksinimli bireylere yönelik tutumlarının toplam puan açısında değişkenlerle ilişkisini tespit etmektir. Bu kapsamda alınan tutum puanlarının dağılımı şöyledir:

18, 20, 27 ve 30 puanı birer kişi, 31 ve 41 puanı üçer kişi, 34 puanı dört kişi, 29, 33, 35, 38, 50, 62 puanı beşer kişi, 43, 45, 46, 59, 64 puanı altışar kişi, 32, 37, 55, 57, 63 puanı yedişer kişi, 36, 39, 40, 44, 58 puanı sekizer kişi, 47 ve 56 puanı dokuzar kişi, 48 puanı 10 kişi, 42, 51, 54 puanı on ikişer kişi, 49 puanı 13 kişi, 52 ve 60 puanı 
on beşer kişi, 61 puanı 16 ve 65 puanı da 26 kişi almıştır. Veriler incelendiğinde 60 ve üzeri puan alan kişi sayısının yüksek olduğu, hatta en yüksek puan olan $65^{\prime}$ i 26 kişinin aldığını görmekteyiz. Bu rakamlar bize, edebiyat öğretmeni adaylarının genel olarak özel gereksinimli bireylere yönelik olarak yüksek oranda olumlu tutumlara sahip olduğunu göstermektedir.

Özel gereksinimli bireylere yönelik tutum puanlarının çalışmaya katılan edebiyat öğretmen adaylarının cinsiyet, yaş, mezun olunan lise, baba ve anne eğitim durumu değişkenlerine göre durumları da aşağıda sunulmuştur.

Tablo 8

Edebiyat Öğretmen Adaylarının Özel Gereksinimli Öğrencilere Yönelik Tutumlarının Cinsiyet Değişkenine Göre Bă̆ımsız Gruplar T-Testi Sonuçları

\begin{tabular}{llllllll}
\hline & cinsiyet & $\mathbf{N}$ & $\overline{\mathrm{X}}$ & ss & Sd & $\mathbf{t}$ & $\mathbf{p}$ \\
\hline \multirow{2}{*}{ tutum } & bayan & 155 & 50,9806 & 10,36068 & \multirow{2}{*}{288} & \multirow{2}{*}{1,733} & \multirow{2}{*}{, 084} \\
\cline { 2 - 6 } & erkek & 135 & 48,8667 & 10,36412 & & & \\
\hline
\end{tabular}

$* \mathrm{p}<, 05$

Tablo 8 incelendiğinde edebiyat öğretmen adaylarının özel gereksinimli bireylere yönelik tutum puanları ile cinsiyetleri arasında istatistiki açıdan anlamlı bir farklılık oluşturmadığı söylenebilir. Öyle ki kız ve erkek öğretmen adaylarının tutum puanları aritmetik ortalama açısından birbirine çok yakın seviyede çıkmıştır.

Tablo 9

Edebiyat Öğretmen Adaylarının Özel Gereksinimli Öğrencilere yönelik Tutumlarının Yaş Değişkenine Göre ANOVA Sonuçları

\begin{tabular}{lllllll}
\hline \multirow{4}{*}{ tutum } & $\begin{array}{l}\text { Varyansın } \\
\text { Kaynağı }\end{array}$ & $\begin{array}{l}\text { Kareler } \\
\text { Toplamı }\end{array}$ & Sd & $\begin{array}{l}\text { Kareler } \\
\text { Ortalaması }\end{array}$ & F & p \\
\cline { 2 - 7 } & $\begin{array}{l}\text { Gruplar } \\
\text { Arası }\end{array}$ & 431,023 & 3 & 143,674 & 1,310 &, 271 \\
& Gruplar İçi & 31141,964 & 284 & 109,655 & & \\
\cline { 2 - 7 } & Toplam & 31572,986 & 287 & & & \\
\hline
\end{tabular}

$* \mathrm{p}<, 05$

Yaş değişkeni edebiyat öğretmen adaylarının özel gereksinimli bireylere yönelik tutumlarına herhangi bir etkisi olmamıştır. Veriler incelendiğinde öğretmen adaylarının yaş durumları arasında ciddi bir farklılık olmadığı da araştırmada elde edilen diğer bir bulgudur. Bu bulgu da özel gereksinimli bireylere yönelik tutumların birbirine benzer şekilde olmasında etkili olmuştur.

Tablo 10

Edebiyat Öğretmen Adaylarının Özel Gereksinimli Öğrencilere yönelik Tutumlarının Mezun Olunan Lise Değişkenine Göre ANOVA Sonuçları

\begin{tabular}{lllllll}
\hline \multirow{4}{*}{ tutum } & $\begin{array}{l}\text { Varyansın } \\
\text { Kaynağı }\end{array}$ & $\begin{array}{l}\text { Kareler } \\
\text { Toplamı }\end{array}$ & Sd & $\begin{array}{l}\text { Kareler } \\
\text { Ortalaması }\end{array}$ & F & p \\
\cline { 2 - 7 } & $\begin{array}{l}\text { Gruplar } \\
\text { Arası }\end{array}$ & 392,624 & 5 & 78,525 &, 729 &, 603 \\
& Gruplar İçi & 23817,041 & 221 & 107,769 & & \\
\hline & Toplam & 24209,665 & 226 & & & \\
\hline
\end{tabular}

$* \mathrm{p}<, 05$

Araştırmada etkisi incelenen bir diğer değişken öğretmen adaylarının mezun oldukları lisedir. Bu kapsamda genel lise, Anadolu lisesi, fen lisesi, Anadolu öğretmen lisesi, meslek lisesi ve süper lise seçenekleri sunulmuş ve alınan cevaplar doğrultusunda özel gereksinimli bireylere yönelik tutumların bu değişkenle istatistiki açıdan anlamlı bir farklılık olup olmadığı belirlenmeye çalışılmıştır. Sonuç olarak tabloda belirtilen sig. değerleri dikkate alındığında mezun olunan lise değişkeninin özel gereksinimli bireylere yönelik tutumlarla arasında anlamlı bir farka sebep olmadığ tespit edilmiştir. 
Tablo 11

Edebiyat Öğretmen Adaylarının Özel Gereksinimli Öğrencilere Yönelik Tutumlarının Anne ve Baba Ĕ̈itim Durumu Değişkenine Göre ANOVA Sonuçları

\begin{tabular}{|c|c|c|c|c|c|c|}
\hline \multirow{4}{*}{$\begin{array}{l}\text { Anne } \\
\text { eğitim } \\
\text { durumu } \\
\text { toplam } \\
\text { puan }\end{array}$} & $\begin{array}{l}\text { Varyansın } \\
\text { Kaynağı }\end{array}$ & $\begin{array}{l}\text { Kareler } \\
\text { Toplamı }\end{array}$ & Sd & $\begin{array}{l}\text { Kareler } \\
\text { Ortalaması }\end{array}$ & $\mathbf{F}$ & $\mathbf{p}$ \\
\hline & $\begin{array}{l}\text { Gruplar } \\
\text { Arası }\end{array}$ & 484,678 & 4 & 121,169 & 1,111 & ,352 \\
\hline & Gruplar İçi & 25090,403 & 230 & 109,089 & & \\
\hline & Toplam & 25575,081 & 234 & & & \\
\hline \multirow{4}{*}{$\begin{array}{l}\text { Baba } \\
\text { eğitim } \\
\text { durumu } \\
\text { toplam } \\
\text { puan }\end{array}$} & $\begin{array}{l}\text { Varyansın } \\
\text { Kaynağı }\end{array}$ & $\begin{array}{l}\text { Kareler } \\
\text { Toplamı }\end{array}$ & Sd & $\begin{array}{l}\text { Kareler } \\
\text { Ortalaması }\end{array}$ & $\mathbf{F}$ & $\mathbf{p}$ \\
\hline & $\begin{array}{l}\text { Gruplar } \\
\text { Arası }\end{array}$ & 654,101 & 4 & 163,525 & 1,504 & ,202 \\
\hline & Gruplar İçi & 24899,215 & 229 & 108,730 & & \\
\hline & Toplam & 25553,316 & 233 & & & \\
\hline
\end{tabular}

$* \mathrm{p}<, 05$

Anne ve baba eğitim durumu, edebiyat öğretmen adaylarının özel gereksinimli bireylere yönelik tutumlarına etkisi olabileceği düşünülen diğer değişkenlerdir. Bu etkinin tespiti için yapılan analiz sonucunda tabloda verilen bulgulara ulaşılmış ve bulgular incelendiğinde bun değişkenlerin özel gereksinimli bireylere yönelik tutuma istatistiki açıdan bir tesirinin olmadığı belirlenmiştir. Bu anlamda anne ve baba eğitim durumu ile edebiyat öğretmenlerinin özel gereksinimli bireylere yönelik tutumları arasında anlamlı bir farklılık yoktur.

\section{SONUÇ VE TARTIŞMA}

Araştırma sonucunda edebiyat öğretmen adaylarının özel gereksinimli bireylere yönelik tutumlarının toplam puan açısından şu şekilde dağılım gösterdiği belirlenmiştir: 18, 20, 27 ve30 puanı birer kişi, 31 ve 41 puanı üçer kişi, 34 puanı; dört kişi, 29, 33, 35, 38, 50, 62 puanı; beşer kişi, 43, 45, 46, 59, 64 puanı; altışar kişi, 32, 37 , 55, 57, 63 puanı; yedişer kişi, 36, 39, 40, 44, 58 puanı; sekizer kişi, 47 ve 56 puanı; dokuzar kişi, 48 puanı; 10 kişi, 42, 51, 54 puanı; 12 kişi, 49 puanı; 13 kişi, 52 ve 60 puanı; 15 kişi, 61 puanı; 16 ve 65 puanı da 26 kişi almıştır. Buna göre 60 ve üzeri puan alan kişi sayısının yüksek olduğu, hatta en yüksek puan olan 65 'i 26 kişinin aldığını ve dolayısıyla edebiyat öğretmeni adaylarının genel olarak özel gereksinimli bireylere yönelik olarak yüksek oranda olumlu tutumlara sahip olduğu belirlenmiştir.

Araştırmada edebiyat öğretmeni adaylarının özel gereksinimli bireylere yönelik tutumları alt boyut bazında da incelenmiştir. Olumsuz tutum, duyarlılık ve beğeni alt boyutları cinsiyet, yaş, mezun olunan lise, baba ve anne eğitim durumu değişkenleri açısından incelenmiştir. Araştırma sonucunda hiçbir alt boyutta ilgili değişkenlere anlamlı bir farklılık tespit edilmemiştir. Dolayısıyla edebiyat öğretmeni adaylarının genel olarak özel gereksinimli bireylere yönelik tutumları öğretmen adaylarının cinsiyet, yaş, mezun olunan lise, baba ve anne eğitim durumuna göre istatistiki açıdan anlamlı bir farklılığa neden olmamıştır. Benzer şekilde Çolak ve Çetin (2014) ile Yıldırım Sarı, Bektaş ve Altıparmak (2010) tarafından yapılan çalışmalarda da cinsiyetlere göre engelli bireylere yönelik tutum puan ortalamaları arasında istatistiksel olarak anlamlı bir fark saptanmıştır. Bunun yanında Yaralı (2015) tarafından yapılan araştırmada “Öğretmen adaylarının cinsiyet değişkenleri dikkate alındığında, özel gereksinimli bireylere yönelik tutumları arasında; sadece "duyarlılık" alt boyutunda bayan öğretmen adayları lehine istatistiksel olarak anlamlı düzeyde bir farklılık olduğu; bunun yanında "Beğeni” alt boyutu, "Olumsuz tutum" alt boyutları ve "ölçeğin geneli”'nde istatistiksel açıdan anlamlı bir farkın olmadığı tespit edilmiştir. Bu durum birçok çalışmada aynı sonuçlara ulaşıldığı ve cinsiyetin özel gereksinimli bireylere yönelik tutuma çok etkisinin olmadığını göstermektedir. Yine 'yaş’ değişkeni de Yaralı (2015) tarafindan yapılan çalışmada ele alınmış ve tarafımızdan bulunan sonuca paralel olarak ölçeğin bütün alt boyutlarında istatistiksel olarak anlamlı bir farklılık tespit edilmemiştir. Ancak Türkiye Cumhuriyeti Başbakanlık Özürlüler İdaresi Başkanlığı tarafından yaptırılan “Toplum Özürlülüğü Nasıl Anlıyor” araştırmasında kullanılan Özürlülere Yönelik Tutum Ölçeği ile elde edilen bulgularda özürlülere yönelik toplumsal tutumların genç yaştakiler lehine daha olumlu olduğu sonucu bulunmuştur.

\section{KAYNAKLAR}

Aydın. O. (2000). Davranış Bilimlerine Giriş. Eskişehir: Anadolu Üniversitesi Yayınları No: 1027.332. Baykoç Dönmez, N. (2010). Özel Gereksinimli Çocuklar ve Özel Ĕ̆itim. (Editör: Baykoç, N.), Öğretmenlik Programları İçin Özel Ĕgitim (ss. 13-26). Ankara: Gündüz Yayıncılık.

Büyüköztürk, Ş., Kılıç-Çakmak E., Akgün, Ö. E., Karadeniz, Ş. ve Demirel, F. (2008). Bilimsel Araştırma Yöntemleri, Ankara: Pegem A Yayıncılık.

Cüceloğlu, D. (2000). İnsan ve Davranışı, İstanbul, Remzi Kitabevi. 
Fishbein,M. ve Ajzen, i. (1975). Belief, attitude, intention, andbehavior:An introductionto theoryandresearch.MA: Addison-Wesley

Gay, L.R., Airasian, P. (2000). Educational Research. New Jersey: Upper Saddle River,.

Millî Ĕ̈itim Bakanlı̆̆ Özel Eğitim Hizmetleri Yönetmeliği, Resmî Gazete, 18.1.2000/23937 Mük

Karasar, N. (2005). Bilimsel araştırma yöntemi. Ankara: Nobel Yayın Dağıtım.

Özgür, İ. (2013). Engelli Çocuklar ve Eğitimi Özel Eğitim. Adana: Karahan Kitapevi.

Özgüven, İ. E. (2002). Bireyi Tanıma Teknikleri. Ankara: Problem Yayınları.

Özkan Yaşaran, Ö. (2009). Normal Gelişim Gösteren Öğrencilerin Özel Gereksinimli Bireylerin Sosyal Kabullerini Sağlamada Kaynaştırmaya Hazırlık Etkinliklerinin Etkisi. Yayımlanmamış Yüksek Lisans Tezi, Anadolu Üniversitesi Eğitim Bilimleri Enstitüsü, Eskișehir.

Phillips, S. L. (2003). Contributing Factors To Music Attitude In Sixth-, Seventh-, And Eighth-Grade Students. Doktora Tezi. Iowa Üniversitesi.

Robbins, S. (1994) Örgütsel Davranışın Temelleri (Çev: Sevgi Ayşe Öztürk) Eskişehir ETAM Basım Yayın.

Sarı H. ve Bozgeyikli, H. (2003). Öğretmen Adaylarının Özel Eğitime Yönelik Tutumlarının İncelenmesi: Karşılaş̧ırmalı Bir Araştırma. Selçuk Üniversitesi Sosyal Bilimler Enstitüsü Dergisi, 183-204.

Sünbül, A. M. (2001) Bir Meslek Olarak Ögretmenlik. Öğretmenlik Mesleğine Giriş. (Edit: Ö. Demirel-Z. Kaya) Ankara: Pegem Yayıncilık.

Tavşancıl, E. (2002). Tutumların Ölçülmesi ve SPSS ile Veri Analizi. Ankara: Nobel Yayıncılık

Temizkan, M. (2008). Türkçe Öğretmeni Adaylarının Öğretmenlik Mesleğine Yönelik Tutumları Üzerine Bir Araştırma, Türk Eğitim Bilimleri Dergisi Yaz 2008, 6(3), 461-486

Türkçe Sözlük, (Erişim Tarihi 2017).

http://www.tdk.org.tr/index.php?option=com_bts\&arama=kelime\&guid=TDK.GTS.59955f3dea48c5.65 779513

Ülgen, G. Eğitim Psikolojisi, Kavramlar, İlkeler, Yöntemler, Kuramlar ve Uygulamalar. Ankara: Kurtiş Matbaası, 1997

Yıldırım, A. ve Şimşek, H. (2005). Sosyal bilimlerde nitel araştırma yöntemleri. Ankara: Seçkin Yayıncılık.

2916 Sayılı Özel Eğitime Muhtaç Çocuklar Kanunu (1983), T.C. Resmi Gazete, 18192, 15 Ekim 1983.

573 Sayılı Özel Ĕgitim Hakkında Kanun Hükmünde Kararname (1997), T.C. Resmi Gazete, 23011, 06 Haziran 1997.

\section{EXTENDED SUMMARY}

Introduction: When the education processes are examined carefully, it is possible to see that the most important building stone is teachers and students. Hence, in this process both teachers and students have important tasks and both elements must work in harmony with each other. This adaptation is even more necessary and important, especially in situations where the student needs special needs. As a matter of fact, many students are special needs within the education and training process and it is important that teachers must be very sensitive and careful to such students, as needs to consider individual differences of each student. Because the educational process of such students is a bit more complicated and teachers need to have sufficient knowledge and skills in this area. So they must have developed an attitude. Attitude has been the subject of many research fields since it takes place in almost every stage of human life. As such, the notion of attitude has been defined in many ways. Ülgen (1997) defines the concept of attitude as a phenomenon that leads to bias in the decision-making process that directs the behavior of the individual. For this reason, the "attitude" concept plays a key role in both the teacher component and the student component in the educational process. In particular, positive attitudes of teachers towards students are effective in the successful execution of education and training processes. As are all the students, the attitude of the teacher towards special needs individuals is also very important. As a matter of fact, such students are more sensitive than normal students. It can be said that the special needs individuals are different from the normal ones from the various angles and this difference makes them different. In our country, various applications are being made in order to minimize or even eliminate this alienation. In his (2009) study Özkan Yaşaran stated that this situation is necessary and pointed out the purpose of this application as follows: "It is necessary for special needs individuals to benefit from equal opportunity in education as individuals who normally develop to live as a member of society. In recent years, changing school policies and laws have helped support the least restrictive environment, it is accepted that they should be educated in the same environment with their peers of special needs individuals and be merged in another way ". This has led to the necessity of teachers to be more attentive, sensitive, attentive and competent. As a matter of fact, decarceration these students that the exclusion by other students, the labelling being blocked by the teacher is the most important element of this application. 
The aim of this study is to determine the attitudes of literature teachers candidate towards the special needs individuals and to examine whether this situation is related to various variables. Within this scope, there are three sub-dimensions within the scope of the attitudes of the researchers towards the special needs individuals. These can be stated as negative attitude, sensitivity and appreciation. Each of these sub-dimensions has been looking at the relationship between the following variables: gender, age, graduated high school, fathers and mothers educational status.

Method: In the study, the relational scan model which has been included in the survey approach from the survey methods hes been used. The study has been structured in the context of relational screening pattern because it aims to determine the attitudes of literature teachers candidates towards the special needs individuals and to investigate whether this situation is related to various variables.

The universe of the research has been constituted literature teacher candidates who continue to the Pedagogical Formation Program of the Faculty of Education of the University of Caucasus. In this context, the research has been carried out in the spring semester of 2016-2017 with a total of 297 students in the Department of Turkish Language and Literature.

In the study, "Attitude Scale for Individuals with Special Needs" developed by Yaral1 (2015) and personal information form developed by the researchers have been used.

In the study, the personal information of the teacher candidates and the answers given to each item in the scale have been entered into the SPSS package program. Then, when the data were analyzed, the attitude scores of all the respondents who were included in the sampling have been calculated and the scores have been scored positive towards negative $5,4,3,2,1$ as considering the positive and negative cues. The data of the students in the study have been analyzed by using frequency (f) and percent (\%) values from the descriptive statistics and according to the arithmetic mean of the levels in the sub-dimensions according to the "Attitude Scale for Individuals With Special Needs".

Findings: The research findings have been analyzed in terms of gender, age, graduated high school, father and mother education status variables, taking into consideration the negative attitudes, sensitivity and appreciation of attitude scale subspecialties of literature student candidates. As a result of the analyzes, there has been no statistically significant difference between these variables and the attitudes of the literature teacher candidates towards the special needs individuals.

Another characteristic that has been analyzed in the study is to determine the relationship between the attitudes of literature teacher candidates towards the special needs individuals and the variables in the total score angle. When we look at the data, we see that the number of people who score 60 and above is high, and even the highest score of 65 is received by 26 people. These figures show us that literature teacher candidates generally have high positive attitudes toward particularly demanding individuals.

Conclusion and Discussion: As a result of the research, it has been found out that the number of students who got a score of 60 and higher is high, and that even the highest score of 65 has been taken by 26 people and therefore the literature teacher candidates generally has higher positive attitudes towards special needs individuals.

The attitudes of the literature teacher candidates to individuals with the special needs in the research have been also examined on the sub-dimension basis. Negative attitudes, sensitivity and liking subscales have been examined in terms of gender, age, graduated high school, father and mother education. As a result of the research, no significant difference has been found in the related variables in any sub-dimension. Therefore, the attitudes of literature teacher candidates towards individuals with special needs has not lead to a statistically significant difference according to gender, age, graduated high school, father and mother education status. Similarly, the studies of Çolak and Çetin (2014) with Yıldırım Sarı, Bektaş and Altıparmak (2010), a statistically significant difference has been found between the average attitude points for disabled people according to gender. In addition, in a study by Yaralı (2015), "When the gender variables of the teacher candidates are taken into consideration, the attitudes towards the individuals with special needs; only a statistically significant difference in favor of female teacher candidates in the "sensitivity" sub-dimension; it has been found that there has been no statistically significant difference between the "Likelihood" sub-dimension, "Negative attitude" sub-dimensions and "Scale general". This shows that in many studies the same conclusions are reached and that gender is not very much influenced by the specific needs of individuals. Again, the 'age' variable has been dealt with in the study conducted by the Yaralı (2015), and no statistically significant difference has been found in all the subscales of the scale parallel to the result obtained by us. 